\title{
Grievances Redressal Mechanism of University's Students in India- Policy and Law
}

\author{
Manish Rohatgi, Meenu Gupta
}

\begin{abstract}
This research paper is based on analysing the grievances of students studying in Universities and the way they are handled. After analysing various books, websites, Acts, reports of committees, articles and case laws on the subject, it is found that the grievances of students may include issues related to admissions, withdrawal from the Course, ragging, attendance, debarring from appearing in exams, non-issuance of admit cards, unfair marking, delayed results, issuance of degree and mark sheets, harassment and discrimination on basis of caste, race, religion or sex etc. But due to weak regulatory mechanism coupled with autonomous behaviour of Indian Universities, the grievances of University's students are not properly addressed. The legal safeguards become essential. We have seen that after ragging was declared an offence, the cases dropped intensely. However, Laws can help to prevent, but not cure. Supreme Court in its decisions observed that it is the duty of teachers to take such care of the pupils as a careful parent would take of his children and they should conduct himself more like some Rishi and also as loco parentis.

Further, the educational institutions and the civil society should take sufficient measures for the safety, security and equality. The civic learning is the need of hour and should be an integral component at each and every level of system of education. Many countries have in place proper civic learning at school as well as in higher education. For instance, USA have specially designed courses, while Some others have a civic education in all courses with themes of inequality, diversity, religious oppression, racism, sexism, classism and the like. Having the widened diversity in India, we badly require a similar structure in our system of education.
\end{abstract}

Key words: Grievance, University, Regulatory Mechanism, Law, Civic Learning.

\section{INTRODUCTION}

Student Grievances right from admission to conferment of degree may include issues Institution making admissions contrary to admission criterion or in contravention of merit list/qualification/eligibility; non-issue of admission prospectus; false information in prospectus, Non-recognised Institutions, discrimination (on basis of caste, race, religion, disability etc), non-refund of Fee, original certificates on withdrawal, Ragging, unfair marking of attendance, debarring from exams, non-issue of Admit Cards, unfair

Revised Manuscript Received on October 22, 2019

Manish Rohatgi, Ph.D. (Law) Research Scholar, Amity University Uttar Pradesh, Sec-125, Noida (U.P.), India.

Email: manishrohatgi@rediffmail.com

Prof. (Dr.) Meenu Gupta, Guide, Amity Law School, Amity University Uttar Pradesh, Sec-125, Noida (U.P.), India.

Email: mgupta1@amity.edu.

marking, delayed Results, Issues related to Marksheet/Degree, harassment etc.

As per the University Grants Commission (UGC) Grievance Redressal Regulations 2012 , "the grievance includes following:

- making admissions contrary to merit determined in accordance with the declared admission policy of the Institute;

- $\quad$ irregularity in the admission process adopted by the institute;

- refusing admission in accordance with the declared admission policy of the institute

- $\quad$ non-publication of prospectus, as specified;

- publishing any information in the prospectus, which is false or misleading, and not based on facts;

- withhold or refuse to return any document in the form of certificates of degree, diploma or any other award or other document deposited with it by a person for the purpose of seeking admission in such institution,with a view to induce or compel such person to pay .any fee or fees in respect to any course or program of study which such person does not intend to pursue ;

- demand of money in excess of that specified in the declared admission policy or approved by competent authority to be charged by such institution;

- $\quad$ breach of the policy for reservation in admission as may be applicable;

- complaints of alleged discrimination of students, from the Scheduled Castes. The Scheduled Tribes, other backward classes;

- non-payment or delay in payment of scholarships to any student that such Institution is committed;

- delay in conduct of examinations or declaration of results beyond that specified in the academic calendar;

- lack of Student amenities as promised or required to be provided by the Institution;

- denial of quality education as promised at the time of Admission/required to be provided.

- unfair and non-transparent evaluation practices

- harassment (including sexual) and victimisation of student."

In India, as per the UGC regulations every College/Institution has to formulate a five-member Student Grievances Redressal Committee.

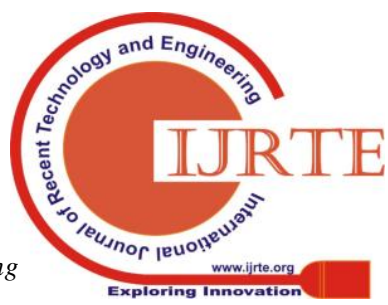


Every Affiliating University's Vice-Chancellor is required to form a Student Grievances Redressal Committee consisting of a senior Professor as its Chairman, 3 other Teachers from affiliating colleges on rotation basis as well as a student representative of college where grievance occurred.

Further University has to appoint an Ombudsman who may be less than the rank of District Judge or a retired Professor with not less than 10 years of teaching experience.

However, there are lacunae in the system. Recently a former DU student Harpal Singh filed a WRIT Petition against Delhi University in Delhi High Court. Hon'ble High Court directed UGC to implement its regulations of 2012 and see that every University has Student Grievances Redressal Committee2 and appoint Ombudsman for addressing the appeal of aggrieved student (s).

\section{PROBLEM IDENTIFICATION}

Due to weak regulatory mechanism combined with autonomous behaviour of Indian Universities, the grievances of University's student are not properly addressed.

\section{RESEARCH METHODOLOGY}

Research methodology is doctrinal in nature where various books, websites, Acts, reports of committees, articles and case laws are referred and critically analysed on the subject.

\section{ANALYSIS}

\section{Student Grievances can be broadly classified as under:}

\section{A. Issues related to Admissions including withdrawals}

Non-issue or false publications of Prospectus, demanding money for admission, making admissions contrary to admission criterion of institution; contravention of merit list/qualification/eligibility, Non-recognised Institutions, discrimination (on basis of caste, sex, race, religion, disability etc.), non-refund of Fee and original certificates on withdrawal etc. are the issues related to the students' admission.

The matter of non-refund of Fee and original certificates on withdrawal was so grave in nature that UGC has to formulate and put in place a fresh guideline on $6^{\text {th }}$ December $2016^{3}$ on Remittance and Refund of Fees and Other Student Centric Issues superseding its public notice dated $23^{\text {rd }}$ April 2007 in this regard as it was turning out to be ineffective. The UGC itself admitted that due to absence of an effective and robust policy the number of Higher Educational Institutions driven by profiteering motivations carrying out shady dealings and malpractices resulting in considerable number of complaints and court cases. Therefore, UGC felt the need for elaborate instructions to curb the malpractices ${ }^{4}$. But the agony is the UGC has taken 10years to realize its mistake due to which malpractices prevailed in Higher Education Institutions and the students remained at the receiving end and have to take the beating and being victimized.
The UGC earlier notification states that if a student leaves after joining the course and seat consequently falling vacant has been filled by another student by the last date of admission then only the student is entitled for refund after necessary deductions.

This has been misused by number of institutions by certifying that no admissions have taken place against the seat vacated by the student by the last date of admission while keep on take new admission beyond the notified last date of admission.

In case of Regional Institute of Cooperative Management, Chandigarh v. Naveen Kumar Choudhary \& ors., "Regional Institute of Co-operative Management, Chandigarh has made a notification through advertisements, etc. and assured about its outstanding reputation as per publicity brochure, etc. It assured $100 \%$ job placement guarantee. Its prospectus mentioned for the batch 2010-12 that the Post Graduate Diploma in Management which would provide was equivalent to Master of Business Administration and recognised by Association of Indian Universities. It was also represented that it was funded by the Ministry of Agriculture, Government of India.

Placing reliance on these representations, all the 6 complainants, took admission in its two years' full-time Post Graduate Diploma in Management (Agriculture Business), for the year 2010-12 batch. The Opposite Party (OP) also contested that it was having healthy relations with Vaikunth Mehta National Institute of Co-operative Management, Pune University and considered it as its parent institute. The complainant deposited a sum of Rs.4,53,500/as per the payment schedule. The complainants completed the aforesaid Post Graduate Diploma in Management (Agriculture Business). They were issued certificates which reflected that those certificates were recognised by the All India Council for Technical Education, Ministry of Human Resources \& Development, Government of India. However, it was not mentioned that the said Diploma was recognised by the Association of Indian Universities as equivalent to Master of Business Administration Degree, meaning thereby that it was only a Post Graduate Diploma in Management. It also did not show that it was equivalent to Master of Business Administration Degree. Consequently, the complainants could not get enrolled themselves for Ph.D. course as according to the UGC norms, it allowed admission only if the Diploma course was certified by the Association of Indian Universities, as equivalent to Masters of Business Administration Degree. The Teachers were not employed as promised. Consequently, complaints were filed with the prayer to refund the amount of Rs.4,53,500/- along with interest @ $18 \%$ p.a. and compensation in the sum of Rs.2,00,000/- mental agony and physical harassment, punitive damages to the tune of Rs.1,00,000/-. The OP contested all these cases. It listed the following defences. The case was barred by time. The students were informed at the beginning of the Session; vide a notice, placed on the Notice Board 
that the Association of Indian Universities had not recognised the Diploma question equivalent to MBA Degree. However, the students continued their studies without demur. It was mentioned in prospectus that the Diploma in question was recognised by the Association of Indian Universities as equivalent to Master of Business Administration Degree. It is explained that the OP had already applied to the Association of Indian Universities for grant of recognition to the Diploma in question as equivalent to Master of Business Administration Degree which was expected at any time. It is denied that any assurance was given to the complainants.

Similarly, large numbers of students were cheated by Indian Institute of Planning and Management (IIPM), Ghaziabad. Indian Institute of Planning and Management was neither a University within the meaning of Section 2(f) of the University Grants Commission Act, 1956 (UGC Act) nor is it a Deemed University declared by the Central Government under Section 3 of the said Act ${ }^{6}$. IIPM is not entitled to confer, or grant, or hold itself out as entitled to confer or grant any Degree. IIPM however in the advertisements being published by it was using the nomenclature of Degree (as defined in Section 22 of the UGC Act) such as BBA Degree and MBA Degree in relation to its Courses / programmes and misleading the students and public at large for significant number of years since its establishment ${ }^{7}$.

\section{B. Ragging}

Ragging is the other issue which comes with student just joining the course, although Supreme Court in 2009 has given strict directions for anti-ragging measures.

Ragging has been one of the most troublesome issues in India. Ragging has become more of a norm than an exception in a number of educational institutes across the country, which has led to lives being shattered and young people being rendered helpless. Some develop mental disorders; some choose to end their lives while many others are also murdered by the force of ragging. One has heard of many stories of those who have suffered such endless trauma and those who haven't had the strength to speak up against such issues.

One of the most pivotal cases of ragging in India occurred in 1996, in which 19-year-old Pon Navarasu's dismembered body was found around different parts of Tamil Nadu. Navarasu was studying at Rajah Muthiah Medical College, Annamalia University in Chidambaram, Tamil Nadu. He was allegedly ragged by a senior, John David, who began physically assaulting him when he refused to strip and lick his footwear.

It was later revealed that David was known to be a bully at the college and went after Navarasu when he realized that the latter's father was the former Vice Chancellor of Madras University. After interrogation, David confessed to the crime and was sentenced to two consecutive life sentences. He was released in 2001 after a Madras High Court acquitted him, only to be put behind bars in 2011 when the Supreme Court overturned the High Court's decision. During his time out, he was working as a BPO employee.
In another case, Aman Satya Kachroo was only 19-years-old when four seniors ragged him to death at Dr Rajendra Prasad Medical College in Himachal Pradesh in 2009. The young medical student suffered head injuries which he later succumbed to. Kachroo had, just a day before his unfortunate death, filed a complaint against the accused for ragging him.

In his complaint, Kachroo claimed that the four accused, Ajay Verma, Naveen Verma, Mukul Sharma and Abhinav Verma, drunk, gathered around 13 first-year students and asked them to slap and hit each other. He also said that Ajay Verma later slapped him seven times. This apparently carried on till 4 am that day. The next day, Aman went to the college hospital complaining of a severe head ache. He succumbed to his head injuries that night.

The four accused students were freed on "good conduct" in 2013. They were re-enrolled in a government college upon their release. They will however not be able to join any government jobs.

Another shocking case of ragging came when in 2012, a 17-year-old aeronautical engineering student, Ajmal PM was set on fire by his seniors! The student was studying at an engineering college in Bangalore, where he was ragged by a group of four seniors who had failed and were in his class. As he went inside the common bathroom, Ajmal could smell thinner and soon enough, the room was set on fire. He suffered $60 \%$ burns on his body and passed away a few days after the incident.

In 2014, a pharmacy student from the Calcutta Institute of Pharmaceutical Technology was found dead near railway tracks in Kolkata. Reports suggested that the 20-year-old was ragged and beaten up by his seniors in college.

Reports claimed that Akash was bullied by the accused continuously during his time in the institute. In fact, others claimed that he was also stopped from taking a very crucial test by the five. His friends helped recognize five suspects who were suspended from the college. It is yet to be determined that they ragged him and it has been taken as a case of suicide.

Recently, IIT Kanpur has suspended 16 IIIrd year B.Tech students for 3 years and 6 others for 1 year in a landmark decision in case of ragging for first time in history of the Institute. Students were accused of thrashing, abusing and forcing juniors to do inhuman acts on $20^{\text {th }}$ August $2017^{8}$.

\section{Attendance: Unfair attendance \& debarring from exams}

Issues can be related to marking of unfair attendance (demanding money etc), debarring from the exams due to shortage of attendance.

In case of Vandana Kandari v. University of Delhi ${ }^{9}$ Court held that "a female student cannot be deprived from her student status or can be detained in any semester on account of the fact that she could not attend the classes 
because of her pregnancy". Court while relying on Sharron A. Frontiero v. Filliot L. Richardson 36 L. Ed. 2d 583 in which the Court held that "Moreover, since sex, like race and national origin, is an immutable characteristic determined solely by the accident of birth, the imposition of special disabilities upon the members of a particular sex because of their sex would seem to violate the basic concept of our system that legal burdens should bear some relationship to individual responsibility held that what is said about the fair sex by Judges fully applies to a pregnant woman because pregnancy also is not a disability but one of the natural consequences of marriage and is an immutable characteristic of married life. Any distinction therefore, made on the ground of pregnancy cannot but be held to be extremely arbitrary".

The Apex Court in the cases of Lata Singh v. State of Uttar Pradesh $^{10}$ and S. Khushboo v. Kanniamal \& Anr. ${ }^{11}$ has freed live-in relationship from being an offence and also in the latter case where it has held that pre- marital sex is not an offence. Supreme Court held that "the society today is changing at a rapid pace and we must be in tune with the realities and not hold on to archaic social mores. Once such a right, however unpopular, is recognized then it cannot be ruled out that there can be more cases of girl students proceeding on maternity leave when while they are still in college. Law should be an instrument of social change and not a defender of it. Motherhood is not a medical condition but a promise."

In case of Kangana Modi v. Kusum ${ }^{12}$, the High Court held that "there would be no relaxation for shortage of attendance"; the legal proposition is similar to as in the case of Kiran Kumari v. Delhi University \& $\mathrm{Ors}^{13}$ where the division Bench of Hon'ble Delhi High Court held that "there is fairly large percentage (34\%) of lectures which a student may miss for number of reasons including sickness or other reasons beyond his/her control in the matter of Delhi University LL.B. students where the minimum attendance requirement is $66 \%$ but were short of attendance".

\section{Exam: Non-Issuance of Admit Cards, unfair marking, delayed Results Marksheet/Degree}

The Delhi High Court (HC) has termed Central Board of Secondary Education (CBSE) decision to scrap its 'moderation policy' as "unfair and irresponsible". A bench of Acting Chief Justice Gita Mittal and Justice Pratibha M Singh said that "the CBSE's decision, which would come into effect from this year, would have a drastic effect on the students ${ }^{14}$."

In Madhumita Das v. University of Calcutta And Ors. ${ }^{15}$, the Calcutta High Court ordered that "the University shall register the name of the petitioner and publish the result of the petitioner of Part I and Part III and Part IV examinations of LLB examination within fortnight from date of order. The decision to debar 'Patrachar Student' is struck down as violative of Articles 14 and 16 of the Constitution of India".

In other case a student, passed out from an affiliated college of Bharathiar University in 2012, joined a company with the help of a provisional certificate on the understanding that he would submit the degree certificate within 10 days. But his attempts to get a degree certificate went in vain, even after applying for it under the tatkal scheme. He says that the office of the Controller of Examinations has been giving him many excuses but not the certificate ${ }^{16}$.

\section{E. Harassment (Discrimination, Sexual Harassment etc.)}

\section{Discrimination}

The suicide of a Dalit research scholar Rohith Vemula at the University of Hyderabad, was major example of discrimination on basis of caste in Indian institutions of higher education, He was one of five Dalit students of the Ambedkar Students Association, who had been suspended by the administration because of their alleged clash with students of the Akhil Bharatiya Vidyarthi Parishad. They had been protesting against this order but the Vermula decided to end his life. His suicide note, states that no one is responsible for his act, which was difficult to be believed. His death underlines the utter failure in addressing the social evil of caste and caste-based discrimination.

The Thorat Committee ${ }^{17}$, constituted to investigate condition of SC/ST students in AIIMS, Delhi had come out with report that there were denied access to sporting and cultural activities forced into ghettoes in the hostel, discrimination by teachers etc. Dalit students chose to end their lives rather than continue their battle. The 11 cases of suicide by students, mostly Dalits, were reported in Hyderabad between 2007 and 2013 in various institutions. In northern India, apart from 2 cases of suicide by Dalit students at AIIMS, the 14 cases of suicide by Dalit students were reported between January 2007 and April 2011.

\section{Sexual Harassment}

"Sexual harassment ${ }^{18 "}$ includes any unwelcome sexually determined behaviour, whether directly or by implication and includes physical contact and advances, a demand or request for sexual favour, sexually-coloured remarks, showing pornography or any other unwelcome physical, verbal or non-verbal conduct of sexual nature.

In case of B.N.Ray v. Ramjas College $\boldsymbol{e}^{19}$, the petitioner is Vice-Principal in Ramjas College of Delhi University. Four male students submitted complaints against him alleging sexual harassment to the College Complaints Committee constituted under Ordinance XV-D of the University of Delhi which prohibits and provides for punishment in cases of sexual harassment. The counsel for the petitioner submitted that the Ordinance is confined to cases of sexual harassment of a woman. Hon'ble Delhi High Court held that "the Ordinance includes, in its ambit, all complaints of sexual harassment made by a member of the University against any other member of the University. The term sexual harassment is wide enough to include an unwelcome sexually determined behaviour, physical contact and advance, demand or request for sexual favour or any other unwelcome physical, verbal or non-verbal conduct of a sexual nature by a teacher qua a male

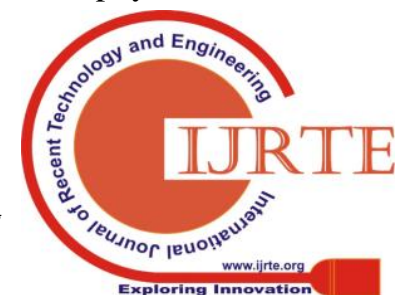


student of the college". Court further held on submission of petitioner that witnesses were not examined in his presence that "in view of the decision of this Court in Bidyug Chakraborty (Prof.) v. Delhi University \& Ors. ${ }^{20}$ as modified by the Supreme Court, it was not obligatory for the Sub-Committee to examine the complainants and other witnesses who were to depose against the petitioner, in his presence. Though the identity of the witnesses was disclosed by the Committee/Sub-Committee to the petitioner, it does not by itself mean that these witnesses were required to be examined in his presence". In Dr. Pushkar Saxena v. Govt. of NCT of Delhi \& Ors. ${ }^{21}$, Delhi High Court held that "in the case of an inquiry into allegations of sexual harassment, cross examination need not necessarily be in the presence of the delinquent since sometimes his very presence may result in putting pressure upon the witnesses and may discourage them from coming out with the truth."

In Hira Nath Mishra and Ors. v. The Principal, Rajendra Medical College, Ranchi and Anr ${ }^{22}$, the Supreme Court held that "the principles of natural justice are not inflexible and may differ in different circumstances. The Court was of the view that the principles of natural justice did not require that the statements of girl students should be recorded in the presence of male students against whom the enquiry was held in that case. The principles of natural justice will, therefore, depend upon the facts and circumstances of each case. "

\section{CONCLUSION}

The grievances of students may include issues related to admissions, withdrawal from the Course, ragging, attendance, debarring from appearing in exams, non-issuance of admit cards, unfair marking, delayed results, issuance of degree and mark sheets, harassment and discrimination on basis of caste, race, religion or sex etc. But due to weak regulatory mechanism coupled with autonomous behaviour of Indian Universities, the grievances of University's students are not properly addressed. The legal safeguards, therefore, become essential. We have seen that after ragging was declared an offence, the cases dropped intensely. In one of the landmark decision Delhi High Court in Vandana Kandari v. University of Delhi (Supra) held that" a female student cannot be deprived from her student status or can be detained in any semester on account of the fact that she could not attend the classes because of her pregnancy." However, Laws can help to prevent, but not cure. In Avinash Nagra v. Navodaya Vidyalaya Samiti and $\mathrm{Ors}^{23}$. the Supreme Court observed that "a duty is cast on the teachers to take such care of the pupils as a careful parent would take of his children and should conduct himself more like some Rishi and also as loco parentis."

Further, proper Civic education at all levels of education can help students to discard undemocratic values and discriminatory practices and sensitises them that the practice of discrimination coupled with caste, sex, religion, race etc. weakens the citizenship values of equity, brotherhood and freedom. Unfortunately, Indian education system lacks less in civic learning that builds good citizens from the youth. "A report by the Association of American Colleges \& Universities, observed that "unlike liberty, civic knowledge, and capability are not bestowed at birth. They are hard won, though education at all levels. Democratic insights and competence are always in the making, always incomplete". It went on to warn that "we dare not be passive about revitalizing civic capacity any more ${ }^{24,}$.

Therefore, civic learning is the need of hour and should be an integral component at each and every level of system of education. Many countries have in place proper civic learning at school as well as in higher education. For instance, USA have specially designed courses, while Some others have a civic education in all courses with themes of inequality, diversity, religious oppression, racism, sexism, classism and the like. Having the widened diversity in India, we badly require a similar structure in our system of education.

\section{REFERENCES}

[1]. www.ugc.ac.in

[2]. https://www.hindustantimes.com/education/ugc-directed-by-delhi-hc-toset-up-grievance-redressal-system-in-all-varsities/story-tBOJCPBExbrls9SnDGjbGM.html

[3]. www.ugc.ac.in

[4]. UGC Notification on Remittance and Refund of Fees dated $6^{\text {th }}$ Dec 2016 pg. 2

[5]. No. 638/2014 National Consumer Disputes Redressal Commission, New Delhi

[6]. W.P. (C) 5937/2010, Delhi High Court

[7]. https://thewire.in/5343/arindam-chaudhuri-iipm-closed

[8]. Hindustan Times dated $10^{\text {th }}$ October 2017

[9]. W.P.(C) No. 8302/2009, Delhi High Court

[10]. AIR 2006 SC $2522 \&$ (2006) 5 SCC 475

[11]. AIR 2010 SC $3196 \&$ (2010) 5 SCC 600

[12]. (2010) 170 DLT 648

[13]. W.P. (C) No. 9143/2007, Delhi High Court

[14]. https://www.indiatoday.in/education-today/news/story/cbses-marks-mod eration-policy-is-unfair-delhi-hc-978733-2017-05-23

[15]. 2005 (1) CHN 313, W.P. 18448W of 2003 decided on 1st March 2004, Calcutta High Court

[16]. https://www.thehindu.com/news/cities/Coimbatore/delay-in-getting-degr ee-certificates-to-cost-jobs/article4920245.ece

[17]. Committee under Chairmanship of Sukhadeo Thorat, Professor Emeritus Jawaharlal Nehru University, and Chairman, Indian Council of Social Science Research.

[18]. Ordinance XV-D of the University of Delhi.

[19]. WRIT PETITION 4427 of 2008, Delhi High Court decided on 21.05.2012

[20]. 2009 VI AD (Delhi)

[21]. WP(C) No. 7592/2001 decided on 16.5.2012.

[22]. (1973) II LLJ 111 SC

[23]. (1997) II LLJ 640 SC

[24]. A Crucible Moment: College Learning and Democracy’s Future”, 2013 